\title{
The challenges and rewards of political memoir writing
}

ROBERT TICKNER

\section{Introduction}

I have unexpectedly been invited to share the 'behind the scenes' story of two autobiographical books that I have written concerning aspects of my public and related personal life. I was at first reticent to undertake the process of sharing the inside account of how a political autobiography is conceived and ultimately carried forward into print. Reticent, because I always knew that I was not a gifted creative writer and that, like the process of making sausages, knowledge of what goes on behind the scenes in the creation of a political memoir —or any book for that matter-is not always entertaining, enlightening or uplifting.

I have agreed to do it, however, because I believe that many more people who have had the privilege to serve in significant ministerial or other senior public roles have their own stories and valuable insights into the process of government, as well as the processes and tactics that lead to the achievement of beneficial social change. Comparatively few commit to the task of writing a political autobiography or memoir, or collaborate in the writing of one. If a parliamentarian has had the opportunity to serve at ministerial level, and their story relates to the achievement of great and positive shifts in public policy, their stories take on a much wider relevance. There is potentially a real utility for the public good in recording and publishing these stories. My intention is to be fully transparent in sharing my own modest 'sausage making' processes, and to do so confidently as I know the primary readers of this reflective article are likely to be academics, writers and maybe even parliamentarians who may take heart from my experiences and one day make their own contribution to the bookshelves of political autobiographies. At least this is my profound hope.

Finally, I should also stress that in writing this background to my books, I have sought to make it practical and down to earth rather than academic in nature. My books, I hope, are written in a similar vein, although I have striven to ensure historical accuracy at all times. I also wanted them to be read by the general community and not just by the academic community. 
I have been privileged to spend 18 years as an elected person in public office, six of them as an elected member of the Sydney City Council, including a very brief period as acting lord mayor during one of the most volatile and high-profile eras of council politics during the twentieth century. During this time, the politics of the council were substantially transformed by the election of a progressive group of Australian Labor Party (ALP) councillors (called Aldermen at that time). We were committed to environmental protection, the defence of the heritage buildings of the city and to many other pioneering innovations in city council policies. We were also prepared to stand up to some rapacious developers who had previously had a dominant role in shaping the policies of previous administrations of the council. There was so much to write about concerning those heady days that I planned to write a book about it all, but I was catapulted unexpectedly into the Parliament of Australia just as my council term ended. My remaining 12 years of public service was as the federal member for Hughes (1984-96), the latter six years as Minister for Aboriginal and Torres Strait Islander Affairs (1990-96). I was honoured to become-and remain - the longest serving minister in that portfolio. Some may not understand, but I honestly believed that to be the Minister for Aboriginal and Torres Strait Islander Affairs was the greatest honour and very best job in the parliament, next to being prime minister.

Arising from my time in public office, I have written two books that are partly autobiographical. However, both have a heavy emphasis on public policy discussion and analysis, and this dimension of my writing distinguishes me from some other political memoirists. To be frank, I have never cared much for the internecine power plays within political parties that form the core of many political memoir narratives. I have always been much more interested in the policy drivers for legislative change, which inspired my interest in public life in the first place, and in what I was able to achieve while I was there. I was never in it for the ride.

My first book, Taking a Stand, was published by Allen \& Unwin in 2001, and it summarises the full six years of my holding the Aboriginal Affairs portfolio. It also puts the reforms of that era in the context of the longer-term history of Aboriginal and Torres Strait Islander public policy, and Aboriginal and non-Aboriginal relations, in Australia. My second book, Ten Doors Down, arose because, at the same time as my ministerial tenure, I went through an extraordinary adoption reunion process. I first met my birth mother on the steps of the Sydney Opera House in early 1993, and later my birth father and then two sisters and two brothers. All this occurred while serving as a minister in what was arguably one the most challenging and volatile portfolios in the Labor Government of Paul Keating.

Twenty-two years after losing my seat in the 1996 election, I was able to secure a publisher for Ten Doors Down. It is a book interspersed with the political backdrop of my ministerial life during what is now known as the 'Mabo debate', in which the country struggled to come to terms with how to respond to the historic High Court decision in 1992 recognising the continuing existence of native title to land 
in this country. I propose to deal with these two books in parallel but sequentially, examining a wide range of issues including my motivations for writing these books; the actual writing process itself; the format they have taken; the soul-searching judgements that were involved along the way; the publishing and editing processes; the major decisions involving covers, designs, titles, endorsements and such; and finally the book launch and aftermath. I should emphasise that the two books are very different, and the background to the writing and publication were also very different. By way of example, securing the publication of Taking a Stand was much easier to achieve by virtue of the early and strong support I received from renowned Australian publisher John Iremonger.

I write now as a person no longer engaged in partisan politics, and not even as a member of a political party, although I remain values driven and engaged as a public policy advocate. By reviving the controversies of my work of almost three decades ago, I will to a degree be surrendering a part of my private life, which these days I value enormously. I will inevitably again be exposing myself to potential public scrutiny and even perhaps criticism from people who still consider themselves to be my political opponents despite that passing of over 25 years since I last sat in the national parliament. In doing this, I am acting consistently with my preparedness over recent years to participate in comparable projects such as the Australian Broadcasting Corporation 'The History Listen' podcast, which dedicated two episodes to the Hindmarsh Island Bridge affair, a political controversy that came into my life in 1994 and stayed there until the year 2001. In that year, the Federal Court of Australia vindicated the Aboriginal women who had claimed for heritage protection, as well as my own actions as minister, and that of key others who had been caught up in the issue. The lesson in all of this I have learnt is that once you are a public figure there is a huge danger of being typecast for life, like the actor who enjoys the 10-year run in the same sitcom and then has to work hard to reinvent themselves in other roles. I hope I have succeeded in escaping this fate.

\section{My motivations}

The primary motivation for Taking a Stand was always very clear in my mind. I wanted to leave a historical record of my time in the portfolio, not only to record the achievements, but also to tell the backstory to some of the major advances in public policy. There were also lessons for those who followed me in the portfolio and in parliament, should they care to read it, because the book also seeks to explain the challenges that remained for our nation to achieve a just reconciliation and to meet the aspirations of Aboriginal and Torres Strait Islander people. I knew by early 1996, as the country moved towards the looming federal election to be held on 2 March that year, that I had lived through a momentous time in Australian public life. I also knew that I was battle-scarred by the process and that I may not be re-elected 
in my own marginal seat. Hughes was always marginal, but had become more so in recent years, and I was assailed on a regular basis on Sydney talkback radio by those commentators who had strongly opposed my support of Aboriginal rights. The issues I had dealt with included the launch of the reconciliation process with the unanimous support of the parliament in 1990, intended to run through until Australia's centenary of Federation on 1 January 2001; support of the leadership of Paul Keating in responding to the aforementioned Mabo judgment; the national response to the Royal Commission into Aboriginal Deaths in Custody; the call for a public inquiry into the Stolen Generations; the establishment of the Indigenous Land Fund to purchase land for Aboriginal and Torres Strait Islander people who would not be able to prove their continuing interest in the land under the Native Title Act 1993; my work in the Northern Territory in achieving a record number of Aboriginal land titles under the Aboriginal Land Rights (Northern Territory) Act 1976 following the successful claims made under that Act; as well as other key issues that were to be subsequently accorded chapter status in my book. I was fortunate with my background as a former Aboriginal Legal Service lawyer to be a participant in these events, and I was truly humbled to have worked with so many outstanding Aboriginal and Torres Strait Islander leaders during this time, such as Lowitja O'Donoghue, and many others across the country.

I knew that there was a lot of Australian political history made in those six years, and I believed it was important that there was a lasting, accurate and intimate insider record of that time. Further, I was confident that I could write it. I also believed that there was much unfinished business in meeting Aboriginal and Torres Strait Islander aspirations. For example, I had sustained serious setbacks in an effort in 1995 to convince the Labor Government of the need to support the Centenary of Federation Infrastructure proposal, which focused on addressing Aboriginal health issues. There was also the issue of the third-stage response to the Mabo decision, namely a social justice package of measures to address Aboriginal disadvantage that had not been delivered during our tenure. I wanted my book to record the successes and offer paths for future policy development.

For me, a public life is a noble enterprise, a judgement I offer not in any sanctimonious or elitist way but because, being a legislator and especially a minister, you do have the potential to change the course of history and to help make our country and sometimes the world a better place. Thus, a further core motivation in writing Taking a Stand was my belief that we devalue our parliaments in this country and we fail to give credit to the fact that there are many people of intelligence, integrity and good will in almost all of our political parties and among the independents. I find that sometimes in the community and in the media, people who themselves are not actively engaged in building a better world by their own social activism are so very ready to cynically dismiss the calling of public life and the absolute necessity of finding ways to bring out the best in our elected members. Cynicism 
in the electorate will never be the wellspring of reform and good government and, in some ways, cynicism breeds more cynicism and alienation on the part of some parliamentarians themselves. We need to find ways to bring idealism and passion to our lobbying processes that inspire progressive change, and to never forget that protest movements, however noble and critical to drive social change, do not deliver change on their own. We need the support of the community and of our elected members to legislate the changes required to tackle injustice, and to drive equity and fairness in our society. I have belonged to and engaged with various community-based social reform movements since I became politically active in my early 20s, and remain involved in this way. In all my work, I have never become cynical about or embittered by parliamentary processes, and I have never lost sight of the fact that securing a parliamentary majority for social reform is every bit as fundamental to achieving social change as a mass demonstration or a million likes on Facebook. Therefore, the work of ministers and parliamentarians is critical, as is our engagement with them. Legislation hardly ever gets through simply on the basis of a clever speech in Cabinet, and many of the really big reforms are so often driven by social movements and the interactions of the people with their parliament.

It is important therefore that people of good will in the parliament who have stories to tell about those processes that help shape the course of history are prepared to share those stories with the rest for us. In my view, that is one of the most important contributions of a good political autobiography. In Taking a Stand, I wanted to show openly and honestly that the work of Aboriginal people and organisations and their many supporters in the community did change the course of history during my time in the portfolio. My book seeks to reveal how that was done; for example, in the lead up to the passage of the Native Title Act.

I had a personal interest in telling the story because I am very proud of my work and leadership, both behind the scenes and publicly, during my ministerial tenure. However, this was never the primary motivation. From the beginning, I was conscious of the need to keep my ego in check, and to ensure that the book did not descend into self-promotion or self-justification. My focus was going to be, unlike most political autobiographies and memoirs, not on the personalities of my fellow ministers but rather on the battle for ideas, the public policy debates and their outcomes. Unlike some others, I was also not motivated by money in writing either of my books, and any surplus from Taking a Stand was directed to the Aboriginal Law Centre at the University of New South Wales. While Taking a Stand is a book with a primary focus on public policy, I have openly acknowledged that my previous experiences (including as a lawyer with the Aboriginal Legal Service) helped shape my political and public policy work as a minister.

My motivation for writing Ten Doors Down was different. Here, I was long driven to honour the reunion with my birth mother, my birth father and two brothers and sisters, who I met when I was in my early 40 s. I also wanted to write respectfully 
about my adopted mum and dad and the great gift they had given me by bringing me up in such a loving environment. However, when I met my birth mother I found out that she had suffered greatly because of my adoption, and at one point she told me that there had never been a day when she had not grieved that adoption. She had also never been able to have any other children as a result of that grief, because of a deep fear that any other child would also be separated from her. She had died some eight years before the book was eventually published in 2020, and much of the book focuses on her life, loss and longing to meet up with her long-lost child. Honouring her in particular became a huge driver for me to write this book. One reason why the story is remarkable is because of the extraordinary coincidences in my narrative, including the fact that when I met my birth mother, she was living only 'ten doors down' from my adopted grandmother.

Another motivation for writing the book was that I wanted to write about the serious public policy issues concerning forced adoption in Australia during the latter half of the twentieth century, which included my own experience. Several chapters of the book either directly relate to or touch on these public policy issues. Again, I was not motivated by money in writing Ten Doors Down, and any proceeds are going to the cause of prison and criminal justice reform through a newly established national organisation I am closely associated with, 'The Justice Reform Initiative'.

Finally, I did intentionally seek to weave into the book numerous aspects of contemporary political developments that I was involved in. I wanted to share this very personal story, to show that parliamentarians (I prefer this to the word 'politician', which has been devalued) are people too! By humanising myself and sharing huge parts of my private life, I wanted to send the message that MPs have lives too, and they are like everyone else in that they have strengths and human frailties, and challenging life situations that they must work through as the daily ministerial workload proceeds apace. I have had a lot of positive feedback about this dimension of the book. I was also conscious that my first book, Taking a Stand, could almost have been a public policy textbook or a work of history (as it modestly was) rather than a personal political autobiography designed for the sharing of the self. There is certainly at least some of that in my earlier book, but it is limited.

\section{Writing the memoirs}

The writing process for the two books was at least in part very different. When I wrote Taking a Stand, internet access was extremely limited in my world. I wrote the entire book by hand in my own awful handwriting. I often compare my writing to that of an eight-year-old child who has comprehensively failed both writing and spelling, and both were truly shocking. The entire book was thus transcribed from my handwriting, and subsequently edited, by my heroic friend Diane Hudson, 
before it went to a publisher. Di was also my office manager for the six years I served as a minister. Without her help and support, I could not have written the book, and that is why I dedicated it to her.

To understand the precarious and fragile nature of the writing process for Taking a Stand, it is important to note that most of it was written during a time when I was experiencing a period of long-term unemployment after the election in March 1996 until early 1998 when I managed to obtain part-time work on the Residential Tenancies Tribunal in New South Wales. Understandably, unemployment and particularly a substantial period of unemployment is bad for personal health, and I wrote the book under very difficult circumstances. However, I did have strong faith in the project from the beginning, and had thought about what the shape of the book may look like before the election. Quietly, I began to accumulate all of the relevant documents I could find in my office that might have proved useful to the writing of a substantial political memoir. I was aware that none of my predecessors as Minister for Aboriginal Affairs (except Gough of course), to the best of my knowledge, had undertaken such a project, and that I had a special obligation to do so given that I was by far the longest-serving minister in that portfolio, and that I had a hell of a story to tell. My efforts to secure my office records, videos and tapes, which contained a treasure trove of historical material, were dealt a terrible blow when one of my staff unfortunately and inadvertently threw out masses of material following the election. Thankfully, key cabinet documents had already been secured, and were not caught up in this deeply regrettable loss of source material.

After the election, when I came to terms with the shock and impact of the loss of my seat, I was then living in a rented shed at Stanwell Park, my marriage having ended a year earlier. I began to slowly write the book, interrupted by a voyage of self-discovery and a road trip around Australia in my late father's old family car that I undertook in the six months following the election itself.

I wrote most of the book in coffee shops, as this had become my way of working from my 20s. I have never been comfortable to work for long stretches desk-bound in an office, and am stimulated if not driven to higher performance when I am surrounded by people in public places like parks, restaurants and, particularly, cafes. When I took up duties with the tribunal in early 1998, I was mostly given country circuits. During the next two years, I did a significant amount of the final writing and preliminary editing of the manuscript during those country trips for the tribunal. I stayed at very modest and sometimes dingy country motels, which formed a regular part of my circuit. I did sometimes think of the reputed stories of Abraham Lincoln working modestly by candlelight in that log cabin. I was of course not equating anything with Abraham Lincoln more than the very modest environments in which I was working and writing, but modest and often dismal they truly were. 
The writing of my second book occurred in very different circumstances. I had done some preliminary work before I went overseas, but I undertook the bulk of this project in 2016 following my return from working as the under-secretary general of the International Red Cross and Red Crescent Federation in Geneva. I had anticipated immediately seeking an executive position comparable to my previous role as CEO of Australian Red Cross when I returned. However, I quickly realised that I had no appetite for taking on such a role, but rather would now claim my life for myself. I decided to devote the rest of my working life to the causes I believed in, and to work on a pro bono basis. This gave me control of my life, and one of the consequences of this control was that I had the time to finish writing this book, which had been building up inside me for some time.

Again, I wrote almost all of the book in local Balmain coffee shops, and in local parks. I also wrote the entire book in an email format, sending these emails to myself and simply adding new text to each successive email. This was how the book took shape. When chapters were finished, the emails would be converted to Word documents, and then I undertook a succession of edits and embellishments as the ideas became clearer to me. I know that many people would think this a crazy way to work, but I must say it works well for me. I never lost any of the work due to IT problems, and I was easily able to convert the emails to text in Word documents.

In the case of both books, I wrote in the style I am most comfortable with, namely that I do not plan the detail of my chapters in advance but write intuitively, with the manuscript taking shape and evolving into different and hopefully improved incarnations over time. In hindsight, this is one of the key bits of advice I would give to people, and that is to dive right in to the writing process. Do not overthink the process of the first chapters. Dive right in and get some words on paper, and you can always come back and edit and reshape what you have done. Nothing beats getting those foundational words and a draft first chapter on the screen in front of you.

In terms of the source materials for Ten Doors Down, I clearly had to undertake research for the public policy and historical references to past adoption laws and policies, and for some other areas such as the chapter on the Stolen Generations (see later). However, most of the book was written as part of my life story, including the history of my early life with my adopted parents, and then the long, drawn-out and complicated developments that occurred as I first met my birth mother, my birth father and then my two brothers and sisters. I was assisted in the telling of this tale by the fact that I possess all of the original letters I had written to my birth parents, and their replies to me. These were all included in the book, and my task was to insert them in a creative way, a task made easier because I had decided to tell the story chronologically. This made reference to and inclusion of the letters easy in the body of the text. 
Writing Ten Doors Down was, in so very many ways, a labour of love, in that I knew I had a cracker of a human-interest story. Of course, I had lived through this story as a personal journey, and it was one that continued to touch me deeply as readers of the book will understand. Although I was perfectly at peace with my life as an adopted person, I had to confront the reality, as the adoption reunion proceeded, that my mother had had a very different experience. As my book reveals, when we first met, she was extraordinarily fragile, and it took at least the first five years of our relationship for her to settle. By then, she knew that I was not going to leave her, and she was to be part of my life forever. But of course, I always carried the sadness and grief of my mother, a sadness that she carried such a well-kept secret for so many years.

So, when I typed her story into my iPad in all those public places, rivers of tears flowed. I do not mind confessing that I would also often be moved to tears again in the years ahead as the book got closer to publication, when I read extracts of what I had written. I continued to find them deeply moving, and intimately personal. I must have been quite a sight in some of those coffee shops with tears streaming down my face as I punched out those many hundreds of emails on my battered little iPad. I should also add that, although I found the writing process for both books a very solitary (and with respect to Ten Doors Down an emotional) one, I also became deeply immersed in the projects and found the effort deeply enjoyable and uplifting in both cases.

The structures and chapter layouts in each book involved different processes and considerations. In the case of Taking a Stand, I had made an earlier decision to divide up the book into chapters based on the particular subject areas of public policy under discussion. Some key examples include 'The Reconciliation Process', 'ATSIC: A Radical Shift Towards Self-Determination', 'Aboriginal Deaths in Custody', 'Getting the Native Title Act Over the Line', 'Heritage, Culture and Hindmarsh Island', and so forth. As the titles of these chapters indicate, I had covered all the major areas of my work in the portfolio and, even today, almost 30 years down the track, so very many of these issues are still on the policy public landscape. Intentionally dividing up the book in this way, I hope I made it accessible to students and to people who want to understand the policy context and timeline of each area of policy development. It does not purport to be just one chronological record. Within each chapter there is a chronological record of what happened in each of the major public policy areas I worked in and have written about.

In Ten Doors Down, the chapter headings show the very different focus of the book on my personal life, with political and public policy chapters and other references interspersed throughout. Most of the chapters were about episodes or developments in my personal journey (such as 'Birth and Adoption', 'Leaving the Nest', 'First Steps Towards Meeting my Birth Mother', 'An Exchange of Letters'). Other chapters, such as 'Adoption Practices in NSW in the 1950s' and 'The Stolen Generations', were 
about broader public policy issues. As can be seen by the chapter headings, they have been given simple titles reflecting the chronological unfolding story of my early life and the adoption reunion, although I have broken them up into chapters that enable the reader to get a comprehensive understanding of what took place in each separate piece of the unification puzzle. In other words, I largely deal with the events leading to the meeting of my father in relatively self-contained chapters and, within the penultimate chapter events are in chronological order to allow that story to unfold.

\section{Searching the soul}

If any author wants to deliver a work of integrity that they can be proud of, it will be necessary to sometimes confront tough questions on possible content that may be embarrassing or cause other difficulties. There will invariably be pressures to engage in self-censorship at various times when issues arise that are politically or personally sensitive to the writer, yet that may need to be included to ensure textual integrity. There are no black and white answers to these questions. I also make no apologies for being an unreconstructed idealist, in that I truly believe that the opportunity to serve as a minister in a national government in Australia is an enormous privilege. In my experience, there are many others in the parliament that share that view on both sides of the political fence. This way of approaching public life played a role in determining the shape and content of the narratives.

By way of example, when I wrote Taking a Stand, I was conscious that an honest account of what was happening behind the scenes during the development of the Mabo response would involve some very sensitive writing. I was not always in agreement with the strategy that Paul Keating was adopting; namely, to seek agreement with state premiers and chief ministers, and then to get Coalition support in the Senate for the passage of the Native Title Act. I never believed that it was possible to do this, and if such an agreement was reached, it would have been at the expense of Aboriginal rights. However, despite the likely adverse consequences for me putting my views on the public record in the book, I determined, in good conscience, that I had no choice but to give a faithfully honest account of these issues. However, I did so making it clear that I was very much in admiration and support for the final view that Paul adopted, with his realisation that the priority had to be given to meeting Aboriginal aspirations. Additionally, at the end of the day, there was a realisation that there was no chance the Coalition would support the legislation in the Senate. This meant that only a majority of ALP, Democrat and Western Australian Greens senators could get the legislation through. I therefore treated Paul Keating exceptionally well in the book for his leadership on this issue, as indeed I believed he was entitled to be treated. 
An example of a second challenge I faced was whether to name the person who I refer to in the book as an ALP colleague who, at one of the most critical times towards the pointy end of the government's Mabo response, was spending much of his time actively undermining me internally, including within the office of the prime minister, in order to advance his own future ministerial prospects. I decided not to name this person, not because I was afraid to do so, but rather because I thought it would divert focus from other, more important, aspects of the book. There was nothing to be gained by naming them. I did, however, keep the reference in the book to the undermining that had occurred, and have since forgiven the person concerned.

I also had to make judgement calls about other people's privacy. For instance, I had to decide whether I would include a fax (some will remember them) sent to me the night before the 1993 election by Michael Wooldridge, then the shadow minister for Aboriginal and Torres Strait Islander affairs. In that very private communication, he celebrated the fact that we had been true to our consciences and achieved a wonderful thing by securing the unanimous passage of the legislation setting up the reconciliation process. I took the view that, although it was obviously a very private communication between two individuals, its publication could only reflect with great credit on him, which it did, and I resolved to quote from it.

Yet another huge and tough judgement call was how I would treat the Hindmarsh Island issue that was, at that time of publication, still before the courts. I decided to be courageous and to take a strong stand in support of the approach I had taken in dealing with the challenging issues before me in that matter, even though there was a danger that a post-publication court decision could be released that could find against me. In that scenario, the words in the book would then come back to haunt me. However, I knew I had acted with integrity, and so I stood my ground in my account as set out in the book, and was soon to be vindicated by the decision of the Federal Court of Australia.

Finally, I should mention that there was one other issue I had to deal with, and that I thought could give rise to major problems. Part of my mission in writing the book was to show the diverse pressures and sources of advice that were coming to the government from bureaucratic departments and agencies. One of those major sources of advice was from the Department of the Prime Minister and Cabinet. I always intended to include quotations and some substantial extracts from departmental documents in the book. I knew that there were potentially serious adverse consequences from quoting these documents, but was also conscious that I would not be the first to breach the cabinet-in-confidence rule. I was aware, for example, that my former colleague Neal Blewett had published his A Cabinet Diary, 
in which there were detailed disclosures of cabinet discussions. ${ }^{1}$ I was aware that no adverse consequences were suffered, although Neal had received a threatening letter from the department before his book was published. I took courage from the fact that he had pressed on, and resolved to continue with my intention to quote from the cabinet submissions and from the advice given to ministers by relevant government departments. These revelations were important to the book, and showed very clearly how difficult it was for Aboriginal advocacy to prevail within the government. Twenty years down the track not one single journalist, political opponent, government official or any other person has ever raised a concern about the publication of these cabinet submissions. This is a good thing, as it is an indication that a more liberal climate of thinking is prevailing around open public debate on public policy issues by former ministers and others.

In relation to sensitive judgment calls that I had to make in relation to Ten Doors Down, there were also ethical challenges. One reality I had to face was that I had to secure the full support of my birth family for the publication of the book, otherwise I could not in good conscience allow it to be published. I was not prepared to sacrifice my newly found beautiful family and my relationship with them for the publication of a book. This meant submitting the manuscript to them all, to my father and brothers and sisters and my stepmother Lola. My birth mother had already passed away in 2012. Submitting the manuscript was a very big deal because, until that time, my father and the family had no idea of the sadness and grief that the adoption had caused my mother, and I was worried that these issues would cause them concern about the publication of the book. I was conscious that I could not allow them to have a blanket veto on content, but I was prepared to listen to any suggestions they had for improvement if indeed there were any. As it turned out they all loved the book, and the very minor concerns they had were about particular words or phrases. They were so minute and, to me, extremely marginal and minor concerns that I could easily accommodate them with no threat to the integrity of the manuscript. All writers of autobiography, I assume, will run into ethical issues of this kind and it is important to make the right calls to maintain the integrity of the manuscript and indeed that of the writer.

\section{Editing and publishing}

My experience of finding a publisher for these books was markedly different. In the case of Taking a Stand, the process was relatively easy. In my years as a political activist in Sydney, I had met the highly respected publisher John Iremonger, who was at that time one of the senior people at Allen \& Unwin. In informal conversation with

1 Neal Blewett, A Cabinet Diary: A Personal Record of the First Keating Government (Kent Town: Wakefield Press, 1999). 
John, in circumstances I do not directly recall, he expressed interest in publishing the book. For that, I am forever grateful. I did not have a literary agent, and my relationship was directly with Allen \& Unwin.

In the case of Ten Doors Down, I was brimming with confidence when I finished the manuscript that I would easily find a publisher. One reason for this confidence was that I had personally paid for editing support from someone I became friends with in Balmain after my parliamentary life had ended. I had shared a house with the young editor Nicola O'Shea who, at that time, was working for HarperCollins. Nearly 20 years later, Nicola was one of Australia's most respected independent editors. She first gave me structural advice on how to reorder the first draft of the chapter titles and suggested helpful deletions. I took this advice and the draft manuscript was significantly improved as a result. Nicola also gave me great advice about how to include dialogue in the book. I was, however, only prepared to include dialogue where I could actually meaningfully recall the conversations that I was writing about. I wanted the book to be honest and true, and therefore ruled out creating any dialogue that I could not personally recall. Again, the book was hugely improved by the inclusion of this authentic dialogue. Nicola also did a detailed copyedit and this also made the book ready for publishing in my view. I realised, of course, that if I was successful in securing a publisher, they would likely appoint an in-house editor to undertake further work.

I have not counted the numbers of personal letters I wrote to publishers, but it must have been close to 20. Again, I did not have a literary agent. Perhaps naively, I included a hard copy of the manuscript and even copies of some of the amazing photos that I thought would be great for the book. I have a collection of approximately 19 personal rejection letters from just about every major publisher in Australia. Almost all of them are respectful letters that acknowledge the beauty of the story I had written but noting that the economics of publishing simply did not stack up, and that the book was not projected to sell sufficient copies to deliver an adequate return to the publisher. This 'heartbreak hill' of rejections was mine to climb. This whole process took nearly two years, and still I had no publisher.

In March 2018, I wrote personally to Henry Rosenbloom, head of Scribe Publications in Melbourne. Finally, in December of that year, I received an email from Henry while I was at my house at Patonga Creek near the mouth of the Hawkesbury River, north of Sydney. I remember vividly where I was in the house when I looked down at the email and read, to my absolute delight, Henry's words: 'I've spent some time mulling over your manuscript. I don't think its commercial prospects are great, but you write sensitively and movingly, and tell an unusual and important story.' He agreed that Scribe would publish the book. I was just delighted by the news that my beloved project had found a home. 


\section{From the publisher's perspective}

In terms of the publisher's final editing process I had very different experiences with the two different books. In the case of Taking a Stand, my allocated sub-editor by Allen \& Unwin was Venetia Somerset, who was based in Victoria. I placed myself in her hands, given that this was my first experience in publishing. At the end of the day, I think the outcome was as I wanted it, in that we produced a historically accurate book, and one that was made better by the publisher's editorial suggestions, including the insertion of a timeline of major events in the relationship between governments and Aboriginal and Torres Strait Islander people. I had not seen one like this before, and although it is not a particularly sophisticated document, many people have found it of great value. One of the great benefits of such a document is that it reminds readers of just how recent are the many atrocities that have been meted out to Aboriginal and Torres Strait Islander people. The so-called 'black arm band view of history' is not some ancient occurrence, and the atrocities and the wounds they created are raw and recent as if they were yesterday. ${ }^{2}$ This clearly shows up in the timeline.

There was also the challenge of doing a substantial index, and this was undertaken in the editing process. It was not, however, a process without challenges, and Di Hudson (herself an accomplished editor) and I had to deal with two totally reviewed versions of the manuscript, checking for historical accuracy as well as other changes in the text before signing off on them. At the end of the day, however, working with the editor, our collective methodical and determined focus on historical accuracy paid huge dividends, because I have never had anyone (including my then political opponents) highlight an error of fact in that book.

In relation to the final editing process for Ten Doors Down, I was allocated Anna Thwaites from Scribe's in-house staff to be my editor. She was very accomplished in her work, and was well suited to a very different style of book. Again, I surrendered myself to the sub-editing process that first involved some suggestions about major structural changes and additions that were easy to accommodate. They recommended that I include an additional chapter in the text focused on the Stolen Generations, which I had already written in and removed from an earlier version of the manuscript, unbeknown to Anna. She also wanted more references to my contemporaneous political experiences in the book, and again this was easy to do because I had already written this material in earlier drafts of the book but had taken it out on the recommendation of others.

2 See Stuart Macintyre and Anna Clark, The History Wars (Carlton, Vic.: Melbourne University Press, 2003). 
In the process of editing both books, I found it important as an author to hold my ground in my dealings with editors on issues of principle. I am, overall, easy to get on with and amenable to suggestions to improve a manuscript, but will always hold my ground on issues of historical accuracy and integrity. I also confess to having personal idiosyncrasies and perhaps some old-fashioned ideas of civility that are manifest in my writing. I remember having long battles in editing Taking a Stand, because I insisted on describing my then political opponents not by their surname but rather as 'Mr' Howard, or 'Mr' Fisher etc. These minor old-fashioned courtesies are important to me in my writing as matters of principle.

\section{Covers, titles and endorsements}

For Taking a Stand, Allen \& Unwin had very clear views on what the cover of the book should look like, and I was quite comfortable to go along with their vision. They did a mock photo of an apparent non-Aboriginal person pouring sand into the hand of an Aboriginal person, in the manner of Gough Whitlam returning the Gurindji lands to Vincent Lingiari while he was prime minister. I had also done this when I returned the Booderee (formally Jervis Bay National Park) to Aboriginal ownership, so I was quite comfortable with the concept.

As for photographs, the publisher really only allowed for one. I chose a shot of Patrick Dodson, Paul Keating and myself, taken after the first meeting of the Council for Aboriginal Reconciliation, which was taken in the Prime Minister's courtyard. My working title was 'No Turning Back', which I thought captured the sentiment that the progress of addressing Aboriginal human rights issues that confronted the nation was not capable of being thwarted by future governments. I honestly believed that, through the momentum generated by the reconciliation process, the progress of further reforms was unstoppable. I could not have believed in the later 1990s that over 20 years later we would have made such limited progress in Closing the Gap. I was dead wrong, because the change of government not only stopped progress but set it significantly backwards, as the country soon understood. So, by the time the book was ready for publishing, I was happy to live with the title 'Taking a Stand', although I was concerned that it could be inadvertently read as somehow acclaiming my own personal record of achievement, which I do not think was ever the intention of the publisher and certainly not mine.

In relation to Ten Doors Down, Scribe Publications, I freely admit, came up with the title for the book, which was much better than my working title of 'For the Love of Family'. We also reached easy agreement on the cover design, which included two photographs that demonstrated powerfully why the book title Ten Doors Down was just perfect. The photographs showed that when I was a small boy, I had been just 10 houses away from my birth mother, Maida, in the same street in western Sydney 
where my adoptive grandmother had lived. Finally, Anna and I reached an easy and quick accommodation and decision on what photographs should be used in the book, and she was a delight to work with.

Securing endorsements for the book is a common practice, and my experience is that this became my responsibility to organise. In the case of Taking a Stand, I managed to get Professor Henry Reynolds, Lowitja O'Donoghue and Mick Dodson to do endorsements for the book. In the case of Ten Doors Down, I again went with Mick Dodson (one of the people conducting the Stolen Generations inquiry), and particularly wanted to make sure he was comfortable with the chapter I had written on the Stolen Generations. I was just a bit sensitive to ensure that, as I had made clear in the book, I had included the chapter not because the Stolen Generations were to be equated in any way with the forced adoption practices in the non-Indigenous community, but because no book about the theft of children and the grief of Australian mothers could possibly be complete without some acknowledgment of the racist assimilation policies that underpinned the taking of Aboriginal children from their mothers. I also sought an endorsement from Nikki Gemmell, who I had met long ago during my ministerial life when she was an ABC journalist in the Northern Territory. Nikki wrote some truly lovely words in support of the book. The third endorsement, successfully sought, was from Anthony Albanese, not only because I respect him very much as a person and that we shared a deep relationship with the late Tom Uren, but also because Anthony had his own momentous family reunion, when he finally found out that his father had not passed away as he had been led to believe, but was in fact still alive in Italy, as were members of his extended family. ${ }^{3}$

\section{Releasing the memoirs}

Though it is not strictly part of the writing and publication process, this piece would not be complete without some feedback to prospective autobiographers and memoirists about the importance of having a book launch and generating significant publicity for a book. I also want to reinforce the importance of the wonderful feedback that can come to a writer following the publication of a book if well written.

I did not get to have a formal launch for Taking a Stand, partly because I was then long-term unemployed, and because the political climate at that time was very much dominated by the advocacy of Pauline Hanson and the policies of the newly elected Howard Government. I did have a number of favourable reviews, but regrettably the book initially did not get the publicity I thought it deserved. Since then, however,

3 For more, see Karen Middleton, Albanese: Telling It Straight (North Sydney: Random House, 2016). 
I truly believe that my book has grown in stature, and I know it is in the catalogues of many of the leading universities and city libraries of the world. It has also been cited as a source by many academics and other social commentators as an inside record of the Indigenous Affairs portfolio during the six years I was the minister.

When it came to Ten Doors Down, I had a series of successful launch events in Sydney, but was also astounded to have achieved a huge amount of publicity associated with the book, with coverage in most capital city newspapers, radio and television interviews, and human interest interviews such as the ABC Conversations program. The Sydney Institute was one of a number of organisations that produced podcasts during the COVID-19 lockdown, when live events were not possible.

The feedback from this book has been truly remarkable and, of all the things I have done in my life, nothing has brought me that degree of warmth and positive response from readers across the political spectrum. By way of example, one Canberra resident wrote a very moving letter to me in which she said she was 'very touched by your sensitivity towards your adopting parents in your search to avoid them feeling hurt. I would like to thank you for writing the book so openly and honestly and to let you know how inspiring it has been for me'.

The story has shown that politicians can be people too, and that readers have derived pleasure from being able to read the beautiful, heart-warming story of my adoption reunion. I hope that, by sharing this background to my two books, I will encourage others to tell their own stories in their own forms. That is my objective. We all learn so much from each other in this world, and there are many parliamentarians with much to share about their political lives and the common humanity that shapes their work. 
This text is taken from Australian Journal of Biography and History: No. 5, 2021, published 2021 by ANU Press, The Australian National University, Canberra, Australia.

doi.org/10.22459/AJBH.05.2021.08 